\title{
Antecedents of Job Performance of Tourism Graduates: Evidence from State University-Graduated Employees in Sri Lanka
}

\author{
Ruwan Ranasinghe \\ Faculty of Management, Uva Wellassa University
}

Received: 14 February 2019. Revision received: 9 May 2019. Accepted: 13 May 2019

\begin{abstract}
Despite the rapid growth of tourism higher education in the past 40 years, uncertainties remain about the content and nature of tourism degrees and their alignment with tourism industry needs. This study aims to identify the impact of tourism education on job performance of tourism graduates. Self-administered questionnaire fielded across the Island secured 260 public sector university tourism graduates' response. Data was analyzed using confirmatory factor analysis and Structural Equation Modeling in Smart-PLS-3. The study showed a positive moderate impact from tourism education on the job performance. Learning outcomes have a moderate positive relationship on job performance. Tourism graduates showed optimistic perception about the tourism education in meeting industry requirements. As the recommendations tourism curriculum must be well planned and enriched with supplementary practical exposure. The faculty members must provide a great support for the undergraduates in accomplishing their carrier objectives and the learning outcomes. Conducive learning environment should be facilitated to reach learning outcomes smoothly. The theoretical contribution of the study lies in the proposed model which elucidates the antecedents of job performance of tourism graduates. Empirically the study contributes for educators and policy makers on tourism education to make their programmes and policies more relevant.
\end{abstract}

Key Words: Tourism Education, Job Performance, Learning Outcomes, Tourism Graduates, State Universities, Sri Lanka, Structural Equation Modeling

JEL Classification: J01, J53, M12

\section{Introduction}

Tourism industry is one of the fastest growing umbrella industries in the world. According to SLTDA (Sri Lanka Tourism Development Authority) in Sri Lanka, tourism is the $3^{\text {rd }}$ largest export earner in the economy, after remittances and textile garments. The direct contribution of Travel \& Tourism to GDP is expected to grow by $6.1 \%$ to LKR842.5billion (6.1 percent of GDP) by 2025 (Mowforth \& Munt, 2015). So for the better performance in the industry, it is necessary to have well trained, educated and skilled workforce. According to the Sri Lanka TSP 2017- 2020 it is one of the high level objective, Tourism and its supporting industries to employ 600,000 Sri Lankans with women accounting for 10\% of the workforce (Sri Lanka Tourism Strategic Plan 2017-2020). Tourism development strategy 2011-2016 mentioned, "The annual output of about 1500 graduates is the industry requirement". The Capital 
alliance annual report (plc, 2014)stated that 9,000 direct employees may be needed per annum for the hotel sector vs. the current 1,500 yearly output of industry graduates.

In Sri Lanka, SLITHM (Sri Lanka Institute of Tourism and Hotel Management) is bringing out close to 4,000 trained personnel per annum. While University of Sabaragamuwa, Uva Wellassa produce 50-150 tourism graduates per annum (Gamage, 2016). Other than that University of Rajarata and Kelaniya also produce tourism graduates in Sri Lanka. Tourism higher education, as a major platform for human capital development for the tourism industry (Ladkin, 2005) has a very close relationship with the economic development of the tourism industry (Wang, Ayres, \& Huyton, 2010). There are some researches has been done on designing the tourism higher education curriculum but the extent to which tourism higher education meets industry needs and the job performance of the graduates has not yet been closely investigated (Wang et al., 2010). Therefore there is a knowledge gap on this area of research. The purpose of this research is to study the job performance and to evaluate the impact of the tourism education as well as to identify the relationship between the learning outcomes and job performance of the tourism graduates and to determine the graduates' perception on tourism education with the industry requirements.

Thus, this study aims to identify the impact of tourism education on the job performance of tourism graduates; to identify the relationship between the learning outcomes and the job performance of tourism graduates; to identify the most influential factors on tourism education. Secondly, the study strives to explore the factors affecting to achieve the position after the graduation and to elucidate the graduates' perception of tourism education versus industry requirements.

According to human capital theory tourism education aims to enhance people's ability in dealing with uncertainties in the tourism industry and managing future changes in the tourism labor market globally. There is an empirical contribution from this research to Sri Lankan tourism higher education as well as the graduate employees' job performance through the intended learning outcomes. This study intends to investigate the impact of the tourism education on the job performance of the tourism graduates in Sri Lanka. Taking in to account the graduates' perception on the tourism education and their job performance this study is expected to clarify above theoretical issues. Tourism education sector, tourism industry, tourism industry service providers and Sri Lankan economy as a whole are expected to be benefited from this study.

\section{Literature review}

A university graduate holding a baccalaureate or master's degree has been a sought commodity on the job market. To the general public the assumption is that more schooling means better jobs (Ariss \& Timmins, 1989). It is assumed also, that individuals with a master's degree generally perform better in a managerial position than do those with a bachelor's degree, and that the individuals with a business degree will perform better in a managerial position than do those with a non-business degree. Many scholars and practitioners have been interested in understanding the relationship between education and performance at work. At the outset, it must be noted that the term "performance" is a very difficult term to define and measure. Given this difficulty the task of trying to establish a relationship between education and job performance is even more difficult. There have been few empirical studies conducted in this area.

It is important to promote the professional competencies as well as generic competencies of future managers to adapt new circumstances and creatively develop the industry, since their 
working conditions cannot be predict. Therefore the role of universities is increasing around the world. Tourism graduates must acquire knowledge and develop skills that enhance their ability to adapt to different unpredictable situations since they should work in multicultural organizations and are in contact with international tourists of various nationalities and ethnic groups (Sangpikul, 2009). This study aims to examine the impact of the tourism education on the job performance of the tourism graduates in Sri Lanka.

\subsection{Job Performance}

Wise (Ariss \& Timmins, 1989) examined, is there any relationship between the quality of one's college, one's academic achievement in that college, and the eventual job performance? He also questioned whether or not such a relationship was exist in nature. Wise had initial problems with the term "performance." From the past many definitions and practices were developed for the understanding of the job performance. According to the business dictionary simply job performance can be defined as "a function of outcomes at work". The work related activities expected of an employee and how well those activities were executed can be defined as 'job performance. However, it is generally agreed that the job performance consists performed on a daily of many interacting variables such as the job itself, the employee and/or the work environment.

\subsection{Learning Outcomes}

Learning outcomes can act as a benchmark for assuring quality and efficiency in higher education and also enable universities to describe courses in an unambiguous way so as to open up education to a wider audience (Maher, 2004). Learning Outcomes are a statement of what a student will know and be able to do at the end of a (degree) program or at the end of each component course (module) of the degree. (Maher, 2004) defines a learning outcome as 'being something that students can do now that they could not do previously and a change in people as a result of a learning experience'.

\subsection{Tourism Education}

Tourism comprises the activities of persons travelling to and staying in places outside their usual environment for not more than one consecutive year for leisure, business and other purposes not related to the exercise of an activity remunerated from within the place visited (Organization, 2005). Education defined as the action or process of teaching someone especially in a school, college, or university: the knowledge, skill, and understanding that you get from attending a school, college, or university (Dictionary, 2018). According to this research tourism education can be defined as "The knowledge, skills and understanding you gain from any education institute regarding the leisure, business and other purposes of travelling, hospitality and events management.

According to a study in USA(2014) revealed that there are around 200 master study programs and more than 1000 bachelor study programs in tourism and hospitality worldwide. Every study program attempts to provide the best curriculum ensuring that graduates develop competencies and skills needed by the industry (Donina \& Luka, 2014). In this study tourism 
education will be examined by using mainly three dimensions such as, curriculum and program, institutional resources and faculty members.

\subsubsection{Curriculum}

There is no any fixed definition for curriculum, but the word curriculum derives from a Latin word, Currere, referring to the running of a course, as in a chariot race (Sharma, 2015). Relatively dating back to the $19^{\text {th }}$ century modern term given, the actual term curriculum was used to describe the classics taught in schools during the classical period of Greek civilization. In the $20^{\text {th }}$ century, the term curriculum broadened to include subjects other than the classics (Sharma, 2015). Tourism curriculum may include, courses related to the Tourism management, educational and training environments, educational materials and information, research projects, field trips, laboratory courses etc.(Mehralizadeh, Dehdashti, \& Kashani, 2017).

A critical analysis of literature indicates a research gap between current curriculum studies and this research. First, a great deal of literature about tourism curriculum studies in Tribe's database (2005) is about tourism education in the United Kingdom and North America. Very little is conducted in the Asia-Pacific region. Secondly, the lack of empirical research on which to base curriculum planning has to some extent been addressed at a general level, but the specific needs of industry remain largely uncharted. Thirdly, most literature was conducted ten years ago. The tourism industry has developed rapidly. Thus an up to date study in industryrelevant tourism education is needed.

\subsubsection{Institutional Resources}

The most commonly used "success" model in higher education is based on institutional resources. According to (Astin, 1985) the resource model equates an "excellent" college or university with such things as the entrance requirements of students, the financial and library resources of the institution, and the quality of faculty as measured by their academic pedigree. Several research projects have noted the link between "objective" measures, such as research productivity, institutional resources, and student entry characteristics, to ratings of institutional or program quality (Wolf-Wendel, Baker, \& Morphew, 2000). In addition, the connection between academic excellence and the presence of institutional resources has been codified through the recent records of national rankings published in such sources as U.S. News and World Report. These rankings are based on the presence of resources at institutions as well as on academic reputation and institutional selectivity (Wolf-Wendel et al., 2000).

\subsubsection{Faculty Members}

What is "good" teaching? The question has been asked various times and has been defined from many different alternative views. Although there is no clearly definitive answer to the question, there are some generally accepted characteristics of "good" academics and teaching situations: enthusiasm, knowledge of the subject area, stimulation of interest in the subject area, organization, clarity, concern and caring for students, use of higher cognitive levels in discussions and examinations, use of visual aids, encouragement of active learning and student discussion, provision of feedback, and avoidance of harsh criticism (Feldman, 1976, 1988; Goldsmid, Gruber, \& Wilson, 1977). In a previous study, researchers assessed the quality of faculty members according to achievements in education, training, research, and scholarship 
(Arimoto, Gregg, Nagata, Miki, \& Murashima, 2012). Previous research reported that faculty members who focused on improving the overall quality of their teaching could enhance the students' level of motivation and higher-order thinking skills (Dehdashti, Mehralizadeh, \& Kashani, 2013). However, investigating whether faculty members influence overall academic performance and outcomes remains an important professional issue (Brown et al., 2011).

\subsubsection{The relationship between learning outcomes and job performance}

A dominant discourse in relation to educational provision to emerge in the last decade is the notion of student employability. Learning outcomes enable universities to express student achievement beyond the narrow boundaries of subject knowledge and to articulate other important skills that are developed during the educational process. Key or transferable skills, relevant professional skills and personal qualities, formerly seen as by-products of the educational process, are now regarded as a core part of studying for a degree. Employers have long argued that they are more interested in what students can 'do' rather than what they 'know' and this added weight to the arguments for the adoption of a learning outcomes approach (Maher, 2004). Whilst the role of higher education in contributing to economic development and student employability may have been implicitly assumed for many years, it is only recently that this has become an explicit requirement for institutions.

\subsubsection{The relationship between tourism education and learning outcomes}

Most evaluation studies in academic environments have focused on the curriculum, teaching and learning methods, student-faculty interactions, and student outcomes (Mehralizadeh et al., 2017)

In a previous study, researchers assessed the quality of faculty members according to achievements in education, training, research, and scholarship (Arimoto et al., 2012). Previous research reported that faculty members who focused on improving the overall quality of their teaching could enhance the students' level of motivation and higher-order thinking skills (Dehdashti et al., 2013). However, investigating whether faculty members influence overall academic performance and outcomes remains an important professional issue (Brown et al., 2011). The study of (Dehdashti et al., 2013) clearly showed that faculty can play a crucial role in predicting educational outcomes. Academic departments offering a degree program at the undergraduate level should encourage faculty members to consider their interactions with learners, qualifications, expertise, and effective learning methods. In academic settings, quality enhancement practices may be introduced to improve the skills of faculty members.

Previous studies have suggested that curriculum design may enhance students' motivation for learning (Watson, Lozano, Noyes, \& Rodgers, 2013). The factor of resources refers to the materials needed for teaching and training students. Learning resources such as the library, computer rooms, office space, and laboratory facilities should be assessed. While evaluation studies in higher education have proposed a range of variables for evaluating academic programs, few studies have investigated the relationships of variables such as curriculum, institutional resources, and properties of the faculty members with learning outcomes. 


\subsection{Conceptual Framework}

Graph 1

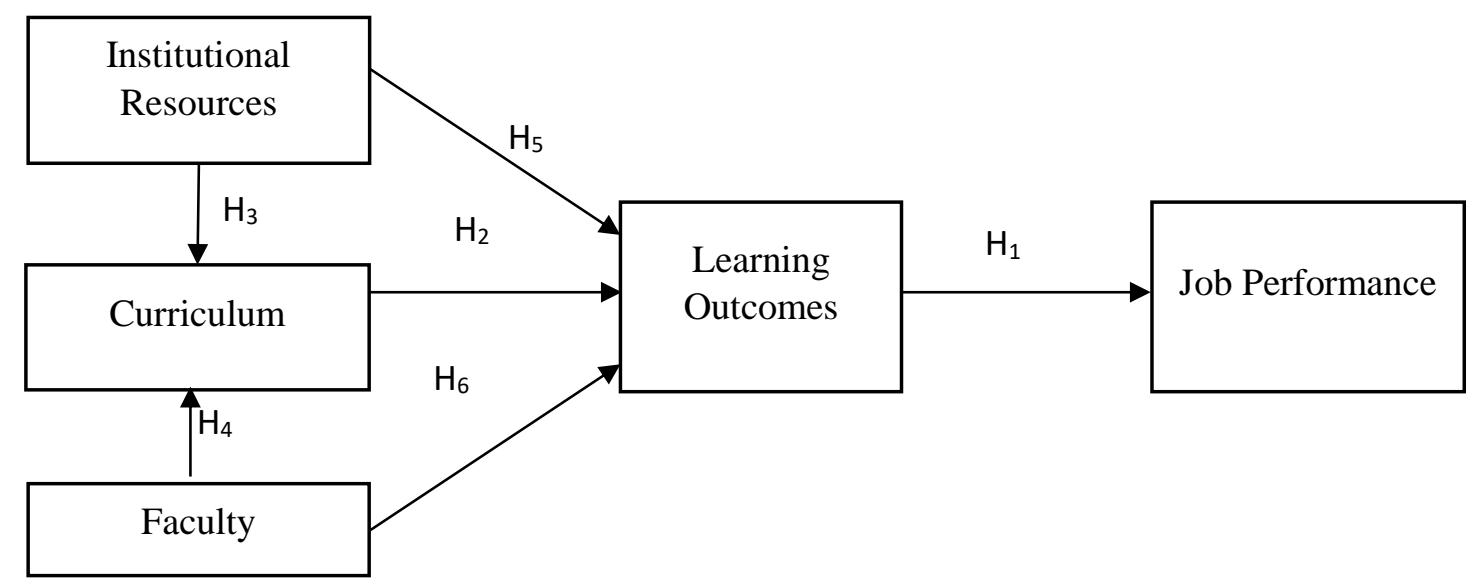

Source : Compiled by author (originally by Mehralizadeh et al., 2017)

\section{Methods}

This study followed quantitative method and data is intended to be collected by using questionnaire in order to fill the knowledge gap and empirical gap in literature. This research assesses the impact of tourism education on the job performance of tourism graduates from the state universities of Sri Lanka. Therefore the target population of the research involves all the Tourism Graduates who are graduated from the State Universities in Sri Lanka. Sample consists of tourism graduates from University of Kelaniya, University of Sabaragamuwa, University of Rajarata and Uva Wellassa University of Sri Lanka. It justified based on the researcher's judgment so as to generalize the findings of research it should be the tourism graduates up to 160 graduates representing 40 from each University. These universities were selected because those are the only state universities conducting tourism related degree programs in Sri Lanka according to the University Grants Commission.

Purposive sampling technique is intended to be used in selecting the above sample. In selecting forty graduates from each university, snowball sampling technique intended to be used. An online survey was used to collect data from the graduates by using five point Likert scale as the measurement. This study was analyzed by using Smart PLS structural equation modeling and SPSS. In order to measure the reliability involved in the research constructs, reliability test was performed to ensure the reliability of measures. According to that Cronbach's alpha value was utilized. As most of the literature widely cited that coefficient alpha exceeds the 0.70 level are reliable. Because of that, the reliability of the research constructs in the acceptable level. Results can be seen in the table below.

\section{Results}


Table 1 Reliability Statistics

\begin{tabular}{l|l|l}
\hline Variable & Cronbach's Alpha & No. of items \\
\hline Curriculum & 0.749 & 11 \\
Faculty & 0.874 & 4 \\
Institutional resources & 0.843 & 5 \\
Learning Outcomes & 0.706 & 5 \\
Job Performance & 0.852 & 12 \\
\hline
\end{tabular}

Source: own calculations

\subsection{Descriptive Statistics}

Table 2 Most significant factors influencing to achieve the job position

\begin{tabular}{cc}
\hline Factor & Mean \\
\hline Adaptability skills & 4.31 \\
Computer skills & 4.21 \\
Customer service skills & 4.17 \\
Oral communication & 4.14 \\
Practical skills & 4.10 \\
Management skills & 4.04 \\
Industry knowledge & 3.98 \\
Creativity & 3.86 \\
Work experience & 3.68 \\
Events Management skills & 3.56 \\
Academic grades & 3.39 \\
Research skills & 3.13 \\
\hline
\end{tabular}

Source: own calculations

The most significant factors which affect to achieve the current job position of the tourism graduates shown in the above table. Adaptability skills, computer skills, customer service skills, oral communication skills, practical skills, management skills and the industry knowledge are the most influencing factors with having higher mean values. Academic grades and research skills gives lesser influence to the job position by having lesser mean values.

Table 3 Graduates Perception on knowledge, skills and abilities through the tourism education

\begin{tabular}{lll} 
& Frequency & Percentage \\
\hline Strongly disagree & 4 & $1.3 \%$ \\
Disagree & 8 & $3.1 \%$ \\
Moderate & 60 & $23.1 \%$ \\
Agree & 135 & $51.9 \%$ \\
Strongly agree & 53 & $20.6 \%$ \\
Total & 260 & $100 \%$ \\
\hline
\end{tabular}

Source: Based on SPSS output 
The graduates' perception on the knowledge, skills and the abilities obtained through the tourism education shown in the above table. According to the output $51.9 \%$ of graduates were agreed that they got necessary knowledge skills and abilities through the tourism education. $20.6 \%$ of them were strongly agreed to that. Therefore, the output concludes that the graduate's perception was that they got necessary knowledge, skills and abilities through the tourism education.

Table 4 Graduates' Perception on the industry exposure through tourism education

\begin{tabular}{lll}
\hline & Frequency & Percentage \\
\hline Strongly disagree & 7 & $2.5 \%$ \\
Disagree & 5 & $1.9 \%$ \\
Moderate & 75 & $28.8 \%$ \\
Agree & 130 & $50.6 \%$ \\
Strongly agree & 42 & $16.3 \%$ \\
Total & 260 & $100 \%$ \\
\hline
\end{tabular}

Source: Based on SPSS output

Perception of the graduates on that they got relevant industry exposure through tourism education shown in the above table. 50.6\% of the sample agreed that they got relevant industry exposure through tourism education. And $28.8 \%$ s' perception was moderate. $16.3 \%$ of the graduates' perception was strongly agree to the statement. Therefore according to the output it can be concluded that the tourism education provides necessary industry exposure to the graduates.

Table 5 Graduates' Perception on the tourism education meets the industry requirements

\begin{tabular}{lll}
\hline & Frequency & Percentage \\
\hline Strongly disagree & 13 & $5.0 \%$ \\
Disagree & 2 & $0.6 \%$ \\
Moderate & 57 & $21.9 \%$ \\
Agree & 125 & $48.1 \%$ \\
Strongly agree & 63 & $24.4 \%$ \\
Total & 260 & $100 \%$ \\
\hline
\end{tabular}

Source: Based on SPSS output

Graduates' perception on the tourism education meets the requirements of the industry shown in the table 4.8 . According to the output $48.1 \%$ of the sample agreed that the tourism education meets the industry requirements of the tourism industry. $24.4 \%$ of them were strongly agreed while $21.9 \%$ graduates' perception was moderate.

\subsection{Scale Refinement}

According to the study of (Mehralizadeh et al., 2017) they evaluated undergraduate occupational health program at the Semnan University of Medical Sciences in Semnan, Iran. They evaluated the perceived opinions by focusing on the associations between alumni perceptions of the learning environment and the learning outcomes of the occupational health program. The survey included descriptive items for alumni self-reporting on the quality of the undergraduate program, as well as items on the demographic characteristics of alumni, such as their involvement in postgraduate studies and employment status. According to the exploratory 
factor analysis of (Mehralizadeh et al., 2017) their questionnaire consisted of 35 items distributed across 4 scales. That version was completed by 97 group of sample from the alumni to perform exploratory factor analysis.

According to the results of the exploratory factor analysis, deleted items with factor loadings less than 0.4 , resulting in the elimination of 7 items and concluded that 28 items are significant. Among that in this research, researcher will confirm 26 items to identify the graduates' perceived opinion on the impact of tourism education on their job performance. According to the study of (Koopmans et al., 2012) they need to develop questionnaire on individual work task performance based on four dimensions, including task performance, contextual performance, adaptive performance and counter-productive work behaviors. An exploratory factor analysis was run by using 47 items and nine items was eliminated due to the factor loadings were less than 0.4 . They concluded that 38 items to measure the job or task performance. Among that researcher used 12 items to confirm the exploratory factors relevant for this particular study. A sample of 260 tourism graduates from all the Sri Lankan state universities issuing tourism related degree programs was used for this study to become the study more reliable and validate. PLS structural equation modeling was used to conduct confirmatory factor analysis.

\subsection{Structural Equation Modeling Analysis}

Partial Least Square (PLS) path modeling method was used to test the proposed model applying tool SmartPLS2. According to the rule of thumb for PLS path modeling is 1 to 10 times of arrows pointed to a variable in the model. Given the six arrows in the model the rule demands only a sample of 60 cases where we have a sample of well above the minimum requirement.

Table 6 Communality of the Modeled Variables

\begin{tabular}{ll}
\hline & Communality \\
\hline & \\
Curriculum & 0.386336 \\
Faculty & 0.727465 \\
Institutional Resources & 0.604320 \\
Learning Outcomes & 0.465989 \\
Job Performance & 0.577420 \\
\hline
\end{tabular}

Source: Based on PLS Algorithm Report

The demographic profiles of the respondents were discussed in the early section of this report. Hence, it will be avoided to prevent repetition here while directly move on to model specification and testing step.

\subsection{Evaluation of Measurement Model}

Reflective measurement models established based on composite reliability, indicator reliability, convergent validity and discriminant validity, (Henseler et al., 2014). High reliability of measures were indicated by all composite reliability values of below Table ( 0.80 to 0.93 ) and are well above the critical value of assessment which is 0.7 (Henseler et al., 2014) An established rule of thumb is that a latent variable should explain a substantial part of each indicator's variance, usually at least $50 \%$. This means that an indicator's outer loading should be above 0.708 since that number squared $(0.7082)$ equals 0.50 .38 indicators was used to run the 
confirmatory factor analysis. Out of 38 indicators six were slightly lower than threshold value for item outer loading which is 0.50 . These indicators were spared, given their contribution to retain composite reliability of the construct (Henseler et al., 2014) Convergent validity of measures was established through Average Variance Extracted (AVE) and this value should be greater than 0.50 according to (Henseler et al., 2014). AVE values in the table below were in between (0.38-0.72) PLS model loadings. As for discriminant validity, cross loadings of indicators were observed. (Henseler et al., 2014) argue that an indicator's outer loading on the related construct should be higher than all of its loadings on the other constructs. Item loadings were compared against its loadings on the other constructs (cross loadings) which were conformed to above standard. Smart PLS 3.0 does not support to identify the multi collinearity between the latent and observed variables.

Table 7 Measurement Model Evaluation

\begin{tabular}{|c|c|c|c|c|}
\hline Variable/Item & $\begin{array}{l}\text { Standardized } \\
\text { Loading }\end{array}$ & t-Statistic & $\begin{array}{l}\text { Composite } \\
\text { Reliability }\end{array}$ & AVE \\
\hline Tourism Curriculum & & & 0.833 & 0.386 \\
\hline $\begin{array}{l}\text { TEC2- Curriculum included courses } \\
\text { related to the tourism degree program }\end{array}$ & 0.601 & $9.460 * * *$ & & \\
\hline $\begin{array}{l}\text { TEC4- Sufficient educational materials } \\
\text { and information were available }\end{array}$ & 0.612 & $9.359 * * *$ & & \\
\hline $\begin{array}{l}\text { TEC5- The institution's administration } \\
\text { system supported students in carrying } \\
\text { out research projects }\end{array}$ & 0.701 & $13.032 * * *$ & & \\
\hline $\begin{array}{l}\text { TEC6- Completing the program, felt } \\
\text { more competent regarding the issues. }\end{array}$ & 0.541 & $7.327 * * *$ & & \\
\hline $\begin{array}{l}\text { TEC8- Course details were available in } \\
\text { written form to students }\end{array}$ & 0.670 & $12.284 * * *$ & & \\
\hline $\begin{array}{l}\text { TEC9- Course sessions were well } \\
\text { organized }\end{array}$ & 0.616 & $6.804 * * *$ & & \\
\hline $\begin{array}{l}\text { TEC11- The program enhanced } \\
\text { interaction among students and between } \\
\text { students and faculty }\end{array}$ & 0.642 & $10.303 * * *$ & & \\
\hline $\begin{array}{l}\text { TEC12- The project internship in a work } \\
\text { environment setting facilitated } \\
\text { professional practice }\end{array}$ & 0.574 & $7.278 * * *$ & & \\
\hline Institutional Resources & & & 0.883 & 0.604 \\
\hline $\begin{array}{l}\text { TEIR1- The library had useful } \\
\text { resources, database, and search engines }\end{array}$ & 0.823 & $23.926 * * *$ & & \\
\hline $\begin{array}{l}\text { TEIR2- There were enough computer } \\
\text { and information technology facilities }\end{array}$ & 0.707 & $10.067 * * *$ & & \\
\hline $\begin{array}{l}\text { TEIR3- The Laboratory (kitchen, } \\
\text { restaurant) equipment were supportive } \\
\text { for learning and research }\end{array}$ & 0.843 & $30.942 * * *$ & & \\
\hline
\end{tabular}


TEIR4- There were technical staff to 0.850 support students

TEIR5- There were sufficient space in 0.643 university buildings for student activities

Faculty Members

TEF1- Faculty members dedicated 0.835 sufficient time to instruct students and support the learning process

TEF2- The faculty had appropriate 0.904 qualifications and expertise in the tourism area, suitable for student learning

TEF3- Faculty members provided students with various learning methods

TEF4- Faculty members had teaching 0.783 and research experiences appropriate for tourism education

Learning Outcomes

LO1- Have sufficient knowledge in 0.514 tourism and be able to understand tourism related concepts

LO2- Have the ability to undertake a 0.651

risk assessment and provide solutions to tourism related problems

LO3- Have the ability to use practical 0.599 knowledge and skills needed in the tourism industry

LO4- Have the ability to carry out 0.759 tourism projects and events as part of a team

LO5- Have understood the needs of self- $\quad 0.842$ based learning

Job Performance

JP1- Worked towards the end result of 0.700 the work

JP2- I was able to perform my work well 0.820 with minimal time and effort JP3- I was able to fulfill my 0.794 responsibilities
0.914

0.727

$34.168 * * *$

$30.660 * * *$

$12.465 * * *$

$57.628 * * *$

$50.525 * * *$

$18.971 * * *$

0.809

0.465

$3.627 * * *$

$11.388 * * *$

$5.237 * * *$

$19.712 * * *$

$31.261 * * *$

0.931

0.577

$11.454 * * *$

$6.642 * * *$

$32.364 * * *$ 
JP4- I came up with creative ideas at 0.702 work

JP5- I took the initiative when there was 0.789 a problem to be solved

JP6- I took on challenging work tasks, 0.820 when available

JP7- I think customers/clients were 0.729 satisfied with my work

JP8- I was able to cope well with 0.852 difficult situations and setbacks at work JP9- I came up with creative solutions to 0.770 new problems

JP10- I was able to cope well with 0.586 uncertain and unpredictable situations at work
$20.512 * * *$

$11.904 * * *$

$19.280 * * *$

$19.291 * * *$

$12.201 * * *$

$34.777 * * *$

$21.471 * * *$

Source: Based on PLS Alogrithm and Bootstrapping ReportsEvaluation of structural model and hypothesis testing

The structural equation model illustrated by the following figure was assessed by coefficient of determination $\left(\mathrm{R}^{2}\right)$ of latent variables. According to (Henseler et al., 2014) $\mathrm{R}^{2}$ values $0.25,0.50$ and 0.75 represent weak, moderate and substantial predictive power of latent variables respectively. Model explains 44 percent of variance of Change of Tourism Education Curriculum (TEC), 23 percent variance of Learning Outcomes (LO) and 35 percent variance of Job Performance (JP) as illustrated in the following figure. To assess the model further, authors implemented PLS iterative bootstrapping procedure by generating 5000 sub samples with 160 cases. The PLS bootstrapping procedure tests whether the specific outer weight (w1) is really zero in the population. The bootstrapping procedure derives the standard error terms which can be compared with $t$ distribution to check whether $-w 1 \|$ is significantly different from zero.

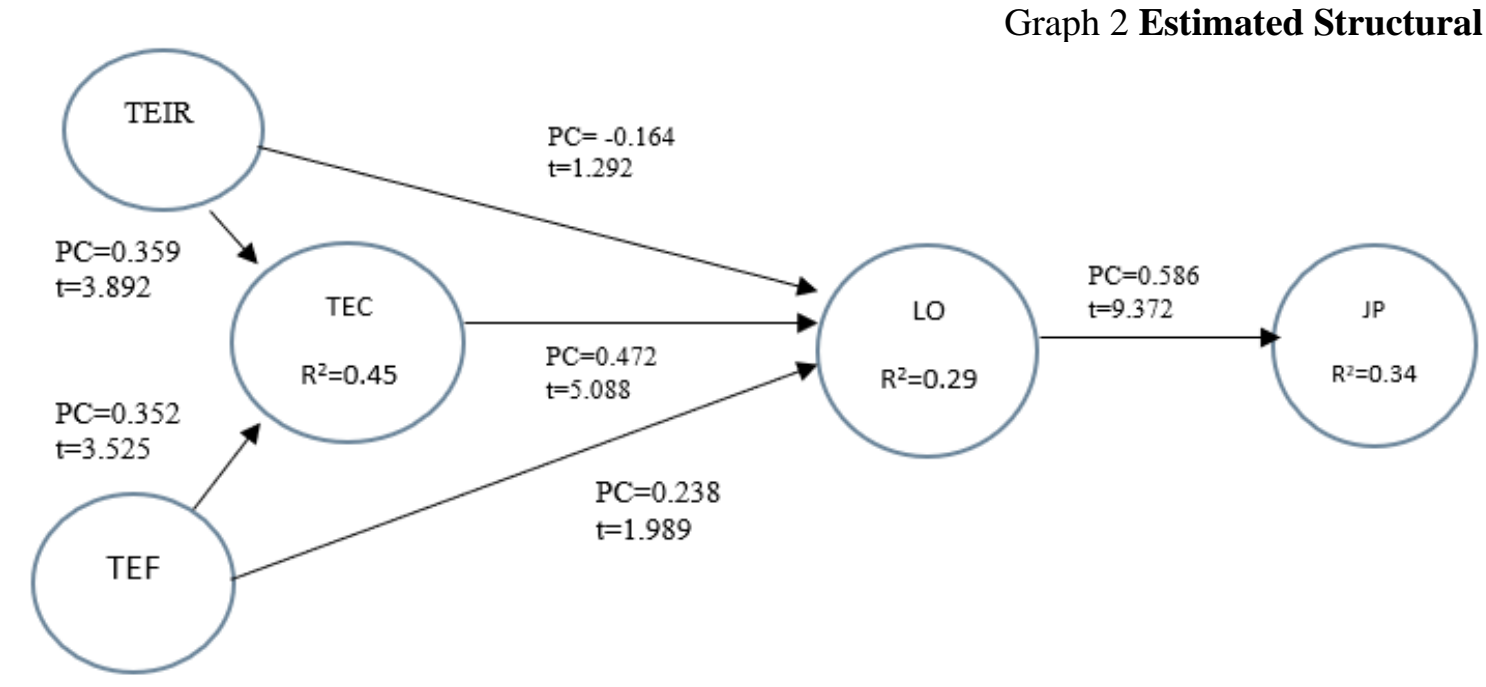

Source: Based on PLS Alogrithm and Bootstrapping 
The table below illustrates the standardized path coefficients (predictive relevance) and relevant $t$ statistics of relationships obtained through PLS bootstrapping performance. Hypothesis 1 proposed a positive relationship between Learning Outcomes and Job Performance. $\mathrm{H} 1$ is supported with a significant path coefficient $(\beta=0.586, \mathrm{t}=9.372, \mathrm{p}<0.01)$. Positive relationship proposed between Tourism Education Curriculum and learning outcomes $(\mathrm{H} 2)$ received a fairly moderate positive path coefficient $(\beta=0.472, \mathrm{t}=5.088, \mathrm{p}<0.01)$.

The positive relationship proposed between Tourism Education Institutional Resources and Tourism Education Curriculum (H3) was also positively supported $(\beta=0.359, \mathrm{t}=3.892, \mathrm{p}$ $<0.01)$. Proposed positive relationship between Tourism Education Faculty Members and Tourism Education Curriculum (H4) was supported indicating a weak positive effect $(\beta=0.352$, $\mathrm{t}=3.525, \mathrm{p}<0.01)$. The positive relationship proposed between Tourism Education Institutional Resources and Learning Outcomes (H5) was rejected since the statistical evidence showed a negative relationship $(\beta=-0.164, \mathrm{t}=1.292, \mathrm{p}<0.01)$. Finally, proposed positive relationship between Tourism Education Faculty Members and Learning outcomes (H6) was positively supported $(\beta=0.238, \mathrm{t}=1.989, \mathrm{p}<0.01)$.

Table 8 Results of Proposed Model (Using PLS-SEM)

\begin{tabular}{|c|c|c|c|c|}
\hline $\begin{array}{l}\text { Hypoth } \\
\text { esis }\end{array}$ & Variable & $\begin{array}{l}\text { Path } \\
\text { Coefficient }\end{array}$ & t-statistic & Status \\
\hline $\mathbf{H}_{1}$ & $\begin{array}{l}\text { Learning outcomes and job } \\
\text { performance }\end{array}$ & 0.586 & 9.372 & Supported \\
\hline $\mathbf{H}_{2}$ & $\begin{array}{l}\text { Tourism Education Curriculum and } \\
\text { learning outcomes }\end{array}$ & 0.472 & 5.088 & Supported \\
\hline $\mathbf{H}_{3}$ & $\begin{array}{l}\text { Tourism Education Institutional } \\
\text { Resources and Tourism Education } \\
\text { Curriculum }\end{array}$ & 0.359 & 3.892 & Supported \\
\hline $\mathbf{H}_{4}$ & $\begin{array}{l}\text { Tourism Education } \quad \text { Faculty } \\
\text { Members and Tourism Education } \\
\text { Curriculum }\end{array}$ & 0.352 & 3.525 & Supported \\
\hline $\mathbf{H}_{5}$ & $\begin{array}{l}\text { Tourism Education Institutional } \\
\text { Resources and Learning Outcomes }\end{array}$ & -0.164 & 1.292 & Rejected \\
\hline $\mathbf{H}_{6}$ & $\begin{array}{l}\text { Tourism Education Faculty } \\
\text { Members and Learning outcomes }\end{array}$ & 0.238 & 1.989 & Supported \\
\hline
\end{tabular}

Source: Based on PLS Reports

\subsection{Blindfolding and predictive relevance of model $\left(Q^{2}\right)$}

Besides, predictive accuracy of model with $\mathrm{R}^{2}$ values, PLS-SEM results have to be evaluated for its predictive relevance which predicts the data points of indicators in reflective measurement models of endogenous constructs and endogenous single-item constructs. The quality standards for $\mathrm{Q}^{2}$ in the structural model is, $\mathrm{Q}^{2}$ values larger than zero for a certain reflective endogenous latent variable indicate the path model's predictive relevance for this particular construct is substantial. However, $\mathrm{Q}^{2}$ zero or less than zero indicates poor predictive relevance for the respective endogenous latent variables.

In order to obtain $\mathrm{Q}^{2}$ we can use PLS blindfolding procedure. Model's predictive relevance $\left(\mathrm{Q}^{2}\right)$ for reflective endogenous variables namely Tourism Education Curriculum $\left(Q^{2}=0.159\right)$, Job Performance $\left(Q^{2}=0.171\right)$ and Learning Outcomes $\left(Q^{2}=0.120\right)$ were satisfactory as illustrated in the following table. 
Table 9 Structural Model's Predictive Relevance $\left(\mathbf{Q}^{2}\right)$

\begin{tabular}{llll}
\hline Latent Variable & SSO & SSE & $\mathbf{1 - S S E / S S O ~}\left(\mathbf{Q}^{2}\right)$ \\
\hline Curriculum & 1280.000 & 1076.277 & 0.159 \\
Learning Outcomes & 1600.000 & 1325.321 & 0.171 \\
Job Performance & 800.000 & 703.621 & 0.120 \\
\hline
\end{tabular}

Source: Based on Blindfolding Report

\section{Discussion}

Tourism education can does a huge impact on the job performance of these tourism graduates. However, there is no any researches are available to identify the impact of tourism education on the job performance with the use of learning outcomes as a mediator. Therefore researcher could identify a knowledge gap as well as an empirical gap. From the observation and literature survey the researcher identified three primary and two seconary research objectives. Based on the objectives researcher formulated six hypotheses and from that hypothesis five hypothesis was accepted. It can be summarized as follow;

Table 10 Summary of the Hypothesis

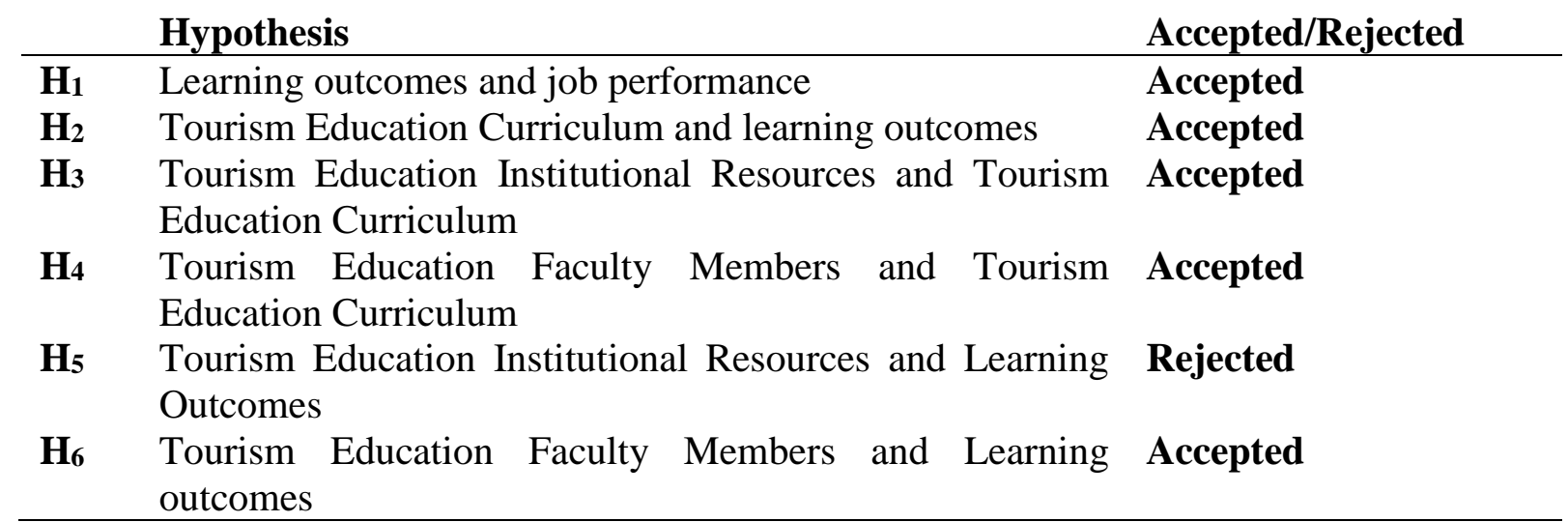

Source: Based on PLS Reports

The first primary objective of this research is to identify the impact of tourism education on the job performance of tourism graduates. In this study tourism education was described by using three independent variables called Tourism Curriculum, Institutinal resources, Faculty members and one mediating variable, learning outcomes. According to the model there is a direct positive fairly moderate impact from tourism curriculum on learning outcomes ( $\mathrm{PC}=0.472)$. Faculty has direct weak positive impacct $(\mathrm{PC}=0.238)$ and an indirect weak positive impact through tourism curriculum $(\mathrm{PC}=0.352)$. Institutional resources has a direct negative impact on learning outcomes $(\mathrm{PC}=-0.164),(\mathrm{t}=1.292)$ and indirect weak positive impact through tourism curriculum. The indirect impact is higher than the direct negative impact. And in this research learning outcomes was used as a mediating variable. According to the study of (Mehralizadeh et al., 2017) insititutional resources has a weak positive relationship with learning outcomes $(\mathrm{PC}=0.26)$ and they have used learning outcomes as the dependent variable. 
And learning outcomes has a direct positive moderate impact on the job performance $(\mathrm{PC}=0.586)$. Therefore we can conclude that tourism education has a moderate positive impact on the job performance of tourism graduates. Hence there can be more factors strongly impact on the job performance other than tourism education. The second primary objective of this research was to identify the relationship between the learning outcomes and the job performance of tourism graduates. In this research learning outcomes was used as the mediating variable. According to the findings of the research the path coefficient value is 0.586 . This is greater than 0.5 , therefore we can identify that there is a strong positive relationship between learning outcomes and the job performance. Hence we can conclude that there is a mediating effect from learning outcomes on the job performance.

The final primary objective of this reaserch was to identify the most influencial factors on the tourism education. In this study researcher used 21 factors to identify the most infuencial factors on the tourism education with the use of a confirmatory factor analysis. Among the 21 items 12 items represent the curriculum construct, 5 items by institutional resources and 4 items by faculty. Through the confirmatory factor analysis four items was excluded since the outer loadings of the factors less than 0.5 significance level. 17 items was confirmed that those factors has the greatest influence to the tourism education. All the four factors under the faculty (TEF1TEF4) was confirmed that there is a great influence by having factor loadings from (0.7830.904). And all the factors under the institutional resources (TEIR1-TEIR5) was confirmed. Those factors has factor loadings range from (0.643-0.850). TEC2, TEC4, TEC5, TEC6, TEC8, TEC9, TEC11, TEC12 the factors under the curriculum was cofirmed that they have a great influence. The factor loadings are range from (0.541-0.701). According to the findings of the research we can conclude that the above mentioned factors are the most influencial factors on tourism education.

he first secondary objective was to identify the factors affecting to achieve the current job position of the graduates. Most of the graduates enter to the industry as trainees to the industry $(66.8 \%)$. But few years later they come to various other positions and to achieve those positions several factors can influenced. According to the findings of the research, adaptability skills, computer skills, customer service skills, oral communication skills, practical skills, management skills and the industry knowledge are the most influencing factors with having higher mean values (4.31-3.56). Academic grades and research skills gives lesser influence to the job position by having lesser mean values.

The last objective of this research was to identify the graduate's perception on tourism versus industry requirements. Researcher used three questions to evaluate this objective. First one was that the graduates' perception on the knowledge, skills and the abilities obtained through the tourism education. According to the research findings $51.9 \%$ of graduates were agreed that they got necessary knowledge skills and abilities through the tourism education. $20.6 \%$ of them were strongly agreed to that. Therefore the output concludes that the graduate's perception was that they got necessary knowledge, skills and abilities through the tourism education.

Second one was that the perception of the graduates' on that they got relevant industry exposure through tourism education. $50.6 \%$ of the sample agreed that they got relevant industry exposure through tourism education and $28.8 \%$ s' perception was moderate $16.3 \%$ of the graduates' strongly agreed with the statement. Therefore, according to the research findings it can be concluded that the tourism education provides necessary industry exposure to the graduates. Final question was graduates' perception on the tourism education meets the requirements of the industry shown in the table 4.8 . According to the output $48.1 \%$ of the sample 
agreed that the tourism education meets the industry requirements of the tourism industry. $24.4 \%$ of them were strongly agreed while $21.9 \%$ graduates' perception was moderate. Therefore we can conclude that the tourism education meets the requirements of the industry. According to the research findings finally we can conclude that tourism graduates have a good perception about the tourism education in order to fulfill the industry requirements.

According to the findings of the analysis, tourism education has a positive moderate impact on the job performance of tourism education. And the structural equation modeling proves that there is a relationship between learning outcomes and the job performance. The confirmatory factor analysis explains the factors which mostly influence on the tourism education. Factors like adaptability skills, computer skills, customer service skills, oral communication skills; practical skills, management skills and the industry knowledge are the factors which affected to achieve the current job positions of the tourism graduates. And tourism graduates have a good perception on the tourism education when related to industry requirements.

All the hypotheses were proven by the study. In terms of the research a significant amount of respondents was captured and the researcher is satisfied with the demographic characteristics of the profile respondents as it to a great extent matched the intended audience which covered up all the state universities proving tourism related degree programs. Therefore the findings through the survey can be thought as being accurate and timely. Moreover, the study will be beneficial to many parties as it strives to understand many insights in tourism education as well as job performance. The results show that the tourism education has a moderate impact on the job performance of tourism education. And the job performance was described weakly by the tourism education. Hence there can be so many other factors which made impacts on the job performance of tourism graduates.

\section{Conclusion}

The recommendations discussed in this section will be those based on the key findings mentioned above. This research study emphasizes on the clarification of antecedents of job performance of the tourism-graduated employees in Sri Lanka with an eye to clarify the areas of concern in this discourse. According to the findings of this research, institutes providing tourism education can be decided that how and which areas should improve when compared to the job performance of the graduates. Further the tourism curriculum must be well planned and rich with more practical exposure to the undergraduates will be a must. The faculty members must provide a great support for the undergraduates in accomplishing their carrier objectives and the learning outcomes of the degree programs. The findings show that there is a negative relationship between learning outcomes and the institutional resources. Therefore the learning environments must facilitate the supportive exposure to the undergraduates in order to get fulfills the learning outcomes of the course. And according to the findings the faculty members and the institutional resources must be supportive to the tourism curriculum. The findings prove that there is a moderate impact from the tourism education to the job performance. Tourism higher education institutes must give a greater emphasis on improving this impact from the tourism education to the job performance. Because there can be number private universities performing well compared to the state universities in the tourism education sector. 


\section{References}

1. Aderibigbe, J. K., Nwokolo, E. E., \& Oluwole, O. J. (2019). EFFECT OF PSYCHOSOCIAL FACTORS ON ORGANISATIONAL CITIZENSHIP BEHAVIOUR AMONG GRADUATE EMPLOYEES IN NIGERIA. Economics \& Sociology, 12(1), 155-367.

2. Ainsworth, W. M., \& Smith, N. (1993). Making it happen: Managing performance at work: Prentice Hall.

3. Airey, D. (1999). Education for tourism-East meets West. International Journal of Tourism and Hospitality Research, 7-18.

4. Albert, T. A.(2016) The Impact of the Hotel Industry on the Competitiveness of Tourism Destinations in Hungary. Journal of Competitiveness, 8 (4), 85-104 https://doi.org/10.7441/joc.2016.04.06

5. Arimoto, A., Gregg, M. F., Nagata, S., Miki, Y., \& Murashima, S. (2012). Evaluation of doctoral nursing programs in Japan by faculty members and their educational and research activities. Nurse education today, 32(5), e1-e7.

6. Ariss, S. S., \& Timmins, S. A. (1989). Employee education and job performance: does education matter? Public Personnel Management, 18(1), 1-9.

7. Barber, E. (2011). Case study: Integrating TEFI (Tourism Education Futures Initiative) core values into the undergraduate curriculum. Journal of Teaching in Travel \& Tourism, 11(1), 38-75.

8. Benson, G. S., Finegold, D., \& Mohrman, S. A. (2004). You paid for the skills, now keep them: Tuition reimbursement and voluntary turnover. Academy of Management journal, 47(3), 315-331.

9. Bryman, A., \& Bell, E. (2011). Ethics in business research. Business Research Methods.

10. Campbell, J. P., McCloy, R. A., Oppler, S. H., \& Sager, C. E. (1993). A theory of performance. Personnel selection in organizations, 3570, 35-70.

11. Cobb, K., Brown, G., Hammond, R., \& Mossop, L. (2015). Alumni-based evaluation of a novel veterinary curriculum: are Nottingham graduates prepared for clinical practice? Veterinary record open, 2(2), pp.116.

12. Dehdashti, A., Mehralizadeh, S., \& Kashani, M. M. (2013). Incorporation of projectbased learning into an occupational health course. Journal of occupational health, 55(3), 125-131.

13. Dictionary, M. W. s. U. (2018). Merriam Webster.

14. Donina, A., \& Luka, I. (2014). The compliance of tourism education with industry needs in Latvia. European Journal of Tourism, Hospitality and Recreation, 5(3), 91-120.

15. Feldman, K. A. (1976). The superior college teacher from the students' view. Research in Higher Education, 5(3), 243-288.

16. Feldman, K. A. (1988). Effective college teaching from the students' and faculty's view: Matched or mismatched priorities? Research in Higher Education, 28(4), 291-329.

17. Gamage, A. S. (2016). The role of human resource management in developing tourism industry in Sri Lanka: a proposed conceptual framework.

18. Goldsmid, C. A., Gruber, J. E., \& Wilson, E. K. (1977). Perceived attributes of superior teachers (PAST): An inquiry into the giving of teacher awards. American Educational Research Journal, 14(4), 423-440.

19. Greensted, C. (2014). Intended learning outcomes. EFMD Global Focus, 8(1), 20-25. 
20. Henseler, J., Dijkstra, T. K., Sarstedt, M., Ringle, C. M., Diamantopoulos, A., Straub, D. W., . . . Calantone, R. J. (2014). Common beliefs and reality about PLS: Comments on Rönkkö and Evermann (2013). Organizational Research Methods, 17(2), 182-209.

21. Jupowicz-Ginalska, A., Paták, M. (2018). Management Of Travel And Transport Destinations' Presentation In The Travel Specialized Print Media. International Journal of Entrepreneurial Knowledge, 6(2), 81-99. doi:10.2478/IJEK-2018-0016

22. Knight, P., \& Yorke, M. (2004). Learning, curriculum and employability in higher education: Psychology Press.

23. Koopmans, L., Bernaards, C., Hildebrandt, V., van Buuren, S., van der Beek, A. J., \& de Vet, H. C. (2012). Development of an individual work performance questionnaire. International journal of productivity and performance management, 62(1), 6-28.

24. Koopmans, L., Bernaards, C. M., Hildebrandt, V. H., De Vet, H. C., \& Van der Beek, A. J. (2014). Construct validity of the individual work performance questionnaire. Journal of occupational and environmental medicine, 56(3), 331-337.

25. Kothari, C. R. (2004). Research methodology: Methods and techniques: New Age International.

26. Kozlowski, S. W., Gully, S. M., Brown, K. G., Salas, E., Smith, E. M., \& Nason, E. R. (2001). Effects of training goals and goal orientation traits on multidimensional training outcomes and performance adaptability. Organizational behavior and human decision processes, 85(1), 1-31.

27. Kumar, S., \& Phrommathed, P. (2005). Research methodology: Springer.

28. Ladkin, A. (2005). Careers and employment. An international handbook of tourism education, 437-450.

29. Luka, I., \& Donina, A. (2012). Challenges of tourism education: Conformity of tourism curriculum to business needs. Academica Turistica, 1(85), 101.

30. Maher, A. (2004). Learning outcomes in higher education: Implications for curriculum design and student learning. Journal of Hospitality, Leisure, Sport and Tourism Education, 3(2), 46-54.

31. Mehralizadeh, S., Dehdashti, A., \& Kashani, M. M. (2017). Evaluation of an undergraduate occupational health program in Iran based on alumni perceptions: a structural equation model. Journal of educational evaluation for health professions, 14 .

32. Morgan, M. (2004). From production line to drama school: higher education for the future of tourism. International Journal of Contemporary Hospitality Management, 16(2), 91-99.

33. Motowildo, S. J., Borman, W. C., \& Schmit, M. J. (1997). A theory of individual differences in task and contextual performance. Human performance, 10(2), 71-83.

34. Mowforth, M., \& Munt, I. (2015). Tourism and sustainability: Development, globalisation and new tourism in the third world: Routledge.

35. Mura, L., Ključnikov, A., Tvaronavičienè, M., Androniceanu, A. (2017). Development Trends in Human Resource Management in Small and Medium Enterprises in the Visegrad Group. Acta Polytechnica Hungarica, Vol. 14, No. 7, pp. 105-122. ISSN: 17858860

36. Organization, W. T. (2005). UNWTO.

37. Özçınar, H. (2015). Mapping teacher education domain: A document co-citation analysis from 1992 to 2012. Teaching and Teacher Education, 47, 42-61.

38. plc, C. A. F. ( 2014). Annual Report 2014. 
39. Ranasinghe. R., (2018). The Contribution of Tourism Income for the Economic Growth of Sri Lanka, Journal of Management and Tourism Rsearch,1.(2), pp 67-84.

40. Rotundo, M., \& Sackett, P. R. (2002). The relative importance of task, citizenship, and counterproductive performance to global ratings of job performance: A policy-capturing approach. Journal of applied psychology, 87(1), 66.

41. Ranasinghe.R., Nawarathna.D. (2018), Determinates of Tourist Loyalty: an extended structural equation model from postwar tourism development context in Sri Lanka, Journal of Management and Tourism Research, 1 (1), 95-113

42. Ranasinghe. R. (2018), Cultural and Heritage Tourism Development in Postwar Regions: Concerns for Sustainability from Northern Sri Lankan Capital Jaffna, Journal of Tourism and Recreation, 4 (1), 1-18

43. Sangpikul, A. (2009). Internationalization of hospitality and tourism higher education: A perspective from Thailand. Journal of Teaching in Travel \& Tourism, 9(1-2), 2-20.

44. Saunders, M. N. (2011). Research methods for business students, 5/e: Pearson Education India.

45. Schmidt, R. A., \& Bjork, R. A. (1992). New conceptualizations of practice: Common principles in three paradigms suggest new concepts for training. Psychological science, 3(4), 207-218.

46. Sharma, A. (2015). Educational tourism: strategy for sustainable tourism development with reference of Hadauti and Shekhawati regions of Rajasthan, India. Journal of Business Economics and Information Technology, 11(4), 1-12.

47. Solà, E. F. (2002). Tourism employment: towards a new paradigm. World Tourism Organization. Human Resources in Tourism: Towards a new paradigm, 223-226.

48. Syama, S., \& Sulphey, M. (2012). Effectiveness of Academic Performance as a Predictor of Job Performance. Indian Journal of Higher Education, 3(2).

49. Wang, J., Ayres, H., \& Huyton, J. (2010). Is tourism education meeting the needs of the tourism industry? An Australian case study. Journal of Hospitality \& Tourism Education, 22(1), 8-14.

50. Watson, M. K., Lozano, R., Noyes, C., \& Rodgers, M. (2013). Assessing curricula contribution to sustainability more holistically: Experiences from the integration of curricula assessment and students' perceptions at the Georgia Institute of Technology. Journal of Cleaner Production, 61, 106-116.

51. Yilmaz, O. D. (2015). Revisiting the impact of perceived empowerment on job performance: Results from front-line employees. Turizam, 19(1), 34-46.

\section{Brief description of Author/Authors:}

Dr. Ruwan Ranasinghe BSc (Hons), MBA, PhD, Head/Department of Tourism Studies, Faculty of Management, Uva Wellassa University, ruwan.fm@gmail.com. Dr. Ranasinghe who is a graduate in Tourism and Hospitality Management has over one and a half decades experience in the tourism industry both as a practitioner and as an academic. He has a number of publications in high impact journals and has presented papers in various international conferences. His main research interests are tourism planning and management, tourism impacts, hospitality management, and tourism destination marketing. 